IRA-International Journal of Education \& Multidisciplinary Studies

ISSN 2455-2526; Vol.03, Issue 03 (2016)

Institute of Research Advances

http://research-advances.org/index.php/IJEMS

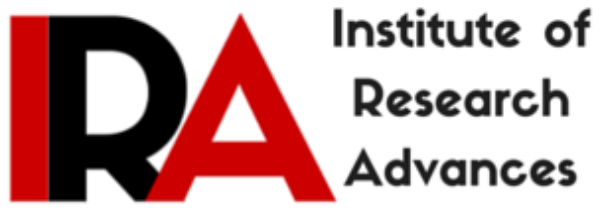

\title{
Technical Folksonomy of Tagging Information
}

\section{Sonali Dapsi}

Librarian, Raja Peary Mohan College, India.

\section{Sudip Ranjan Hatua}

Asst Prof. Rabindra Bharati University, Kolkata, India.

DOI: $\underline{\text { http://dx.doi.org/10.21013/jems.v3.n3.p6 }}$

\section{How to cite this paper:}

Dapsi, S., \& Hatua, S. (2016). Technical Folksonomy of Tagging Information. IRA International Journal of Education and Multidisciplinary Studies (ISSN 2455-2526), 3(3). doi:http://dx.doi.org/10.21013/jems.v3.n3.p6

(C) Institute of Research Advances

\section{(cc) EY-NC}

This works is licensed under a Creative Commons Attribution-Non Commercial 4.0 International License subject to proper citation to the publication source of the work.

Disclaimer: The scholarly papers as reviewed and published by the Institute of Research Advances (IRA) are the views and opinions of their respective authors and are not the views or opinions of the IRA. The IRA disclaims of any harm or loss caused due to the published content to any party. 


ABSTRACT
The Study of the various articles published in Library and Information Science
Journals in the resent times shows that the keywords provided by the authors along
with their articles are mostly uncontrolled. They are basically phrases. In spite of the
knowledge of controlled vocabulary and various subject heading scheme they mostly
are using natural word and sentences to represent the thought content of their
research outcomes. This is generating new trends of representing subjects known as
technical folksonomy.

Keywords: Control vocabulary, Folksonomic Vocabulary, Technical Folksonomy.

\section{Introduction:}

The concept of Folksonomy has come into consideration after the usage of Computer where the new words are being uploaded .The term was coined in 2003 by an information architect, Thomas Vander Wal [10]. It is a neologism consisting of a combination of the words folk and taxonomy. Taxonomy is derived from the Greek words, taxis and nomos. Taxis mean Classification and nomos means Management. In spite of the knowledge of controlled vocabulary and various subject heading scheme they mostly are using natural word and sentences to represent the thought content of their research outcomes. This is generating new trends of representing subjects known as technical folksonomy.

\section{Literature Review:-}

Catherine Lyons viewed that combining cataloguing and other standard metadata practices with user-developed tags and Folksonomies is a good way to improve subject access to resources [9]. Slavko Knett told that the business world has of course discovered the considerable commercial potentials of folksonomy [13].

Ikki Ohmukai, Masahiro Hamasaki, and Hideaki Takeda said that social bookmark system using several metadata and personal network constructs a community-based ontology [2]. ZIXIN WU said that tagging communities are featured Web 2.0 phenomenon, where users describe a Web resource by using keywords (called tags) [11].

Terrell Russell said that Contextual Authority Tagging is the use of Folksonomies to discover and define Cognitive authority through reputation within communities of users [3]. Francisco Echarte, Jose Javier Astrain, Alberto Córdoba, Jesus Villadangos told that Ontology's and tagging systems are two different ways to organize the knowledge present in Web[6]. Alan Said, Robert Wetzker Winfried Umbrath and Leonhard Hennig investigated the problem and recommended during the first months of the collaborative tagging community Cite ULike[1]. Torben Knerr said that collaborative tagging represents the process by which many users describe resources (e.g. web pages or photos) with free-from keywords (tags). Web technologies to develop ontology for Folksonomies, making interoperability and automated processing feasible [10]. Emanuele Quintarelli said that Folksonomies attempt to provide a solution by introducing an innovative distributed approach based on social classification [5].

Massimiliano Dal Mas says that folksonomy gives an overview of current trends in manual indexing on the Web. Digital resources with tags (keywords) share their annotations with other users through tagging system [8]. Fabian Abel analyzed 
the impact of tags on information retrieval [2]. Jesse Vig said that present tagging applications design the system [9]. Fabian Abels, Matteo Baldoni said that with the advent of Web 2.0 tagging became a popular feature in social media systems. People tag diverse kinds of content, e.g. products at Amazon [1]. Min Gyo Chung said that collaborative tagging activities that proposed scheme maintain video bookmarks, which contain some temporal or positional information about videos [4].

\section{Problem Identification:-}

1>Trends of usage phase, natural Language ,folksonomy are using in the authors in Library and Information Science journals are increasing since last two decades;

2>There is hardly found any attempt to build up a model system for folksonomical terms.

\section{Hypothesis :-}

1) Trends of usage of phrase, natural Language ,folksonomy by the authors in Library and Information Science journals in India are increasing since last two decades;

2> There is hardly found any attempt to build up a model system for folksonomical terms.

\section{Objective:-}

The objectives of this study are:-

a. To identify keywords available in the articles of Library and Information Science journals published in India during 1998 to 2012 and use them for the folksonomical study.

b. To find out the trends of usage and observe their pattern e.g. control vocabulary, phrases, folksonomy etc.

c. To design a model system on folksonomic vocabulary.

\section{Scope of the study:-}

The scopes of this present work are listed as follows-

- The subject scope restricted to Library and Information Science

- The geographical coverage restricted to Library \& Information Science journals published in India;

- The time coverage is 1998-2012;

- Journals published by professional Associations and Institutions and LIS departments in India;

- Language covers the English.

\section{Methodology:-}

For collecting necessary data for the study, survey method has been practiced. The research design of the present study is based on descriptive design and probability sampling method. The sampling procedure selected for the study is based on stratified sampling.

Data has been categorized as follows-

i) Journals published by Library and Information Science Departments of various Universities.

ii) Journals published by professional body and Association.

iii) Journals published by Institution or organization. 
Among LIS Departments sample selection has been made by following criteria -

i) University selected from four zones East, West, North, South

ii) Departments which are 25 years or more have considered from each zone.

For professional body only national body and Association have been considered who are publishing LIS Journals in English Language.

For Institution and organization have been considered who are publishing LIS Journals in English Language.

\section{Data Collection:}

Study has been made of each and individual journal from above set of samples. The Total numbers of Universities calculated all over India is 514 and Library and Information Science Department available within these Universities are 178. Among 178 Universities we have found only 57 departments are 25 years or more old. The 57 departments we have been consulted through direct communication and e-mail. Unfortunately most of them replied as they don't published journal regularly. Only 7 LIS departments found who publishing journals regularly in English Language are. Apart from the 7 department, 3 journals published by Professional Association in national level institutions have taken into consideration for this study.

\begin{tabular}{|l|l|}
\hline No of Total University & 514 \\
\hline No of LIS Departments & 178 \\
\hline No of Departmental consulted (Sample sample size) & 57 \\
\hline No of Department who published journal of LIS & 7 \\
\hline No of National Association & 3 \\
\hline No of Institution & 3 \\
\hline
\end{tabular}

Table 1: Study in Research area (Sample size)

. Finally we have listed 7 Departments which have published Library and Information Science Journals and provides keywords most of their articles during 1998-2012 time span. The list of those departments has given in the table 2 .

\begin{tabular}{|l|l|l|l|}
\hline $\begin{array}{c}\text { Sl } \\
\text { No }\end{array}$ & \multicolumn{1}{|c|}{ University Name } & \multicolumn{1}{|c|}{ Place } & \multicolumn{1}{|c|}{ Journals Name } \\
\hline 1 & University of Delhi & Delhi & $\begin{array}{l}\text { Journal of Library \& Information Science } \\
\text { (JLIS) }\end{array}$ \\
\hline 2 & University of Kashmir & Kashmir & $\begin{array}{l}\text { Trends in Information Management, } \\
\text { (TRIM) }\end{array}$ \\
\hline 3 & University of Calcutta & Kolkata & $\begin{array}{l}\text { Calcutta University Journal of } \\
\text { Information Studies(CUJLIS) }\end{array}$ \\
\hline 4 & $\begin{array}{l}\text { Rabindra Bharati } \\
\text { University }\end{array}$ & Kolkata & $\begin{array}{l}\text { RBU Journal of Library and Information } \\
\text { Science(RJLIS) }\end{array}$ \\
\hline 5 & $\begin{array}{l}\text { University of North } \\
\text { Bengal }\end{array}$ & North Bengal & $\begin{array}{l}\text { Advances in Library and Information } \\
\text { Science(NALIS) }\end{array}$ \\
\hline 6 & Jadavpur University & Kolkata & $\begin{array}{l}\text { Librarian: A Journal of Library and } \\
\text { Information Science(LJLIS) }\end{array}$ \\
\hline 7 & Vidyasagar university & Midnapur & $\begin{array}{l}\text { VU journal of Library and Information } \\
\text { science(VJLIS) }\end{array}$ \\
\hline
\end{tabular}


IRA-International Journal of Education \& Multidisciplinary Studies

\begin{tabular}{|l|l|l|l|}
\hline 8 & NISCAIR & Delhi & $\begin{array}{l}\text { Annals of Library and Information } \\
\text { Studies (ALIS) }\end{array}$ \\
\hline 9 & $\begin{array}{l}\text { Sarada Ranganathan } \\
\text { Endowment for Library } \\
\text { Science }\end{array}$ & Karnataka & $\begin{array}{l}\text { SRELS Journal of } \\
\text { Information } \\
\text { Management(SJIM) }\end{array}$ \\
\hline 10 & $\begin{array}{l}\text { Defence Scientific } \\
\text { Information Delhi } \\
\text { Documentation Centre }\end{array}$ & $\begin{array}{l}\text { DESIDOC Journal of Library \& } \\
\text { Information Technology(DJLIT) }\end{array}$ \\
\hline 11 & $\begin{array}{l}\text { Indian Association of } \\
\text { Special Library and } \\
\text { Information Centre Lolkata }\end{array}$ & IASLIC Bulletin(IB) \\
\hline 12 & $\begin{array}{l}\text { Indian Library } \\
\text { Association }\end{array}$ & Delhi & $\begin{array}{l}\text { Journal of Indian Library } \\
\text { Association(ILSB) }\end{array}$ \\
\hline 13 & $\begin{array}{l}\text { University Library } \\
\text { Teacher's Association }\end{array}$ & $\begin{array}{l}\text { Andhra Pradesh } \\
\text { (Hydrabad) }\end{array}$ & $\begin{array}{l}\text { Pearl : A Journal of Library and } \\
\text { Information Science(PJLIS) }\end{array}$ \\
\hline
\end{tabular}

Table 2: Collecting data (sample size)

From the table 2 we have found that total 13 Population collected from the different articles during 1998-2012. We have been found the uses of data are sample size. By studying all the journals listed in table 2. We have found following data given in table 3

Date Collection Statistics:-

\begin{tabular}{|l|l|l|l|l|l|l|}
\hline $\begin{array}{l}\text { Numbe } \\
\text { r of } \\
\begin{array}{l}\text { Journal } \\
\text { studies }\end{array}\end{array}$ & $\begin{array}{l}\text { Numbe } \\
\text { r of } \\
\text { Volume }\end{array}$ & $\begin{array}{l}\text { Numbe } \\
\text { r of } \\
\text { articles }\end{array}$ & $\begin{array}{l}\text { Total } \\
\text { terms } \\
\text { foun } \\
\mathrm{d}\end{array}$ & $\begin{array}{l}\text { Uniqu } \\
\text { e No } \\
\text { of } \\
\text { terms }\end{array}$ & $\begin{array}{l}\text { Total } \\
\text { Uncontrolle } \\
\text { d } \\
\text { vocabularies }\end{array}$ & $\begin{array}{l}\text { Unique no } \\
\text { of } \\
\text { uncontrolle } \\
\mathrm{d} \\
\text { vocabulary }\end{array}$ \\
\hline 13 & 322 & 2638 & 3604 & 2159 & 2924 & 1958 \\
\hline
\end{tabular}

Table 3: Data collection Statistics

The Used terms available with the article are 3604 among which only 680 terms are found in various popular standard vocabulary tools used laid the LIS professionals. The remaining 2924 terms are not found any of the available standard vocabulary tools. These may be called technical folksonomy. These terms are given in table 3 .

\subsection{Data Analysis:-}

We have analysed the data as per following sequence-

i) Each and every 2638 articles from 322 volumes have been thoroughly studied and listed 3604 terms/phrases etc. Provided by the author/ editor along with their respective article.

ii) We have listed five established Controlled Vocabulary tools given in the table (4) and compare each and every term and phrases with these tools and find their availability or appearance on those tools.

iii) Separated Controlled Vocabulary terms and uncontrolled Vocabulary.

iv) Analyse the growth pattern of those listed uncontrolled vocabulary.

v) Analyze the frequency of uncontrolled vocabulary. 
IRA-International Journal of Education \& Multidisciplinary Studies

\begin{tabular}{|l|l|l|}
\hline S1 No & Title of the Books & Edition \\
\hline 1 & $\begin{array}{l}\text { Library of Congress Subject } \\
\text { Heading }\end{array}$ & $25^{\text {th }}$ ed,2002 \\
\hline 2 & Sears List of Subject Heading & $10^{\text {th }}$ ed,1972 \\
\hline 3 & Dewey Decimal Classification & $23 \mathrm{ed}, 2011$ \\
\hline 4 & Colon Classification & $6^{\text {th }}$ ed, $27^{\text {th reprint } 2006}$ \\
\hline 5 & Thesaurus & $\begin{array}{l}\text { http://www.thesaurus.com/ } \\
\text { (retrieve from 01.3.2012) }\end{array}$ \\
\hline
\end{tabular}

Table 4: List of Comparative standard tools

.Year wise Growth of all control terms in all journals

\begin{tabular}{|c|c|c|c|c|c|c|c|c|c|c|c|c|c|c|c|c|}
\hline $\begin{array}{l}\text { Journ } \\
\text { al } \\
\text { Name }\end{array}$ & $\begin{array}{l}9 \\
8\end{array}$ & $\begin{array}{l}9 \\
9\end{array}$ & $\begin{array}{l}\text { 0 } \\
\text { 0 }\end{array}$ & $\begin{array}{l}\mathbf{0} \\
\mathbf{1}\end{array}$ & $\begin{array}{l}\mathbf{0} \\
2\end{array}$ & $\begin{array}{l}\mathbf{0} \\
\mathbf{3}\end{array}$ & $\begin{array}{l}0 \\
4\end{array}$ & $\begin{array}{l}0 \\
5\end{array}$ & $\begin{array}{l}0 \\
6\end{array}$ & $\begin{array}{l}0 \\
7\end{array}$ & $\begin{array}{l}0 \\
8\end{array}$ & $\begin{array}{l}\text { 0 } \\
9\end{array}$ & $\begin{array}{l}1 \\
\mathbf{0}\end{array}$ & $\begin{array}{l}1 \\
1\end{array}$ & 12 & $\begin{array}{l}\text { Tot } \\
\text { al }\end{array}$ \\
\hline IB & 0 & 0 & 0 & 1 & 5 & 7 & 4 & 6 & $\begin{array}{l}1 \\
8 \\
\end{array}$ & $\begin{array}{l}2 \\
6 \\
\end{array}$ & $\begin{array}{l}1 \\
9 \\
\end{array}$ & $\begin{array}{l}2 \\
6 \\
\end{array}$ & $\begin{array}{l}1 \\
7 \\
\end{array}$ & $\begin{array}{l}2 \\
0 \\
\end{array}$ & 32 & 181 \\
\hline ALIS & & & & & & & & & & & 1 & & & 1 & 33 & 35 \\
\hline DJLIS & & & & & & & & & & & & & & 4 & 81 & 85 \\
\hline TIM & & & & & & & & 2 & 7 & 3 & 7 & 4 & $\begin{array}{l}1 \\
1\end{array}$ & $\begin{array}{l}1 \\
4\end{array}$ & 21 & 69 \\
\hline SJIM & $\begin{array}{l}1 \\
1\end{array}$ & $\begin{array}{l}2 \\
0\end{array}$ & $\begin{array}{l}1 \\
3\end{array}$ & $\begin{array}{l}1 \\
6\end{array}$ & $\begin{array}{l}2 \\
6\end{array}$ & $\begin{array}{l}1 \\
4\end{array}$ & $\begin{array}{l}1 \\
1\end{array}$ & $\begin{array}{l}1 \\
2\end{array}$ & $\begin{array}{l}0 \\
9 \\
\end{array}$ & $\begin{array}{l}0 \\
4\end{array}$ & $\begin{array}{l}1 \\
0\end{array}$ & $\begin{array}{l}1 \\
7\end{array}$ & $\begin{array}{l}1 \\
5\end{array}$ & $\begin{array}{l}1 \\
6\end{array}$ & 05 & 199 \\
\hline PJLIS & & & & & & & & & & & & & & & 17 & 17 \\
\hline LJLIS & & & 1 & & 1 & 3 & 4 & 4 & & & 3 & 1 & & & & 17 \\
\hline RJLIS & & & & & & & & & & & 1 & & 3 & & & 4 \\
\hline $\begin{array}{l}\text { CUJLI } \\
\mathrm{S}\end{array}$ & & & & & 3 & 3 & & & & & & 6 & 1 & & 2 & 15 \\
\hline $\begin{array}{l}\text { NALI } \\
\mathrm{S} \\
\end{array}$ & & & & & & & & & & & & & & 2 & & 2 \\
\hline JLIS & & & & & & & & & & & & & $\begin{array}{l}1 \\
1\end{array}$ & & & 11 \\
\hline ILAB & & & $\begin{array}{l}1 \\
0 \\
\end{array}$ & 9 & 5 & & & & & 3 & & 1 & 7 & 8 & 2 & 45 \\
\hline & $\begin{array}{l}1 \\
1\end{array}$ & $\begin{array}{l}2 \\
0\end{array}$ & $\begin{array}{l}2 \\
4\end{array}$ & $\begin{array}{l}2 \\
6\end{array}$ & $\begin{array}{l}4 \\
0\end{array}$ & $\begin{array}{l}2 \\
7\end{array}$ & $\begin{array}{l}1 \\
9\end{array}$ & $\begin{array}{l}2 \\
4\end{array}$ & $\begin{array}{l}3 \\
5\end{array}$ & $\begin{array}{l}3 \\
6\end{array}$ & $\begin{array}{l}3 \\
9\end{array}$ & $\begin{array}{l}5 \\
6\end{array}$ & $\begin{array}{l}6 \\
5\end{array}$ & $\begin{array}{l}6 \\
5\end{array}$ & $\begin{array}{l}19 \\
3\end{array}$ & 680 \\
\hline
\end{tabular}

Table 5 Year wise Growth of all control terms in all journals

For consulting table 5, we can see from the above table that the Control term/ Keywords Phrases used in various Journals released during a span of fifteen years starting from the year 1998 to 2012.The used of control terms in the starting years 1998 and 1999 was nil, which gradually increase from the year 2000 and reached its maximum level in the year 2012 which was around 680 numbers.

Year wise growth of Uncontrolled term in all journals:

\begin{tabular}{|c|c|c|c|c|c|c|c|c|c|c|c|c|c|c|c|c|}
\hline $\begin{array}{l}\text { Jour } \\
\text { nal } \\
\text { Nam } \\
\text { e }\end{array}$ & $\begin{array}{l}9 \\
8\end{array}$ & $\begin{array}{l}9 \\
9\end{array}$ & $\begin{array}{l}\mathbf{0} \\
\mathbf{0}\end{array}$ & 1 & 2 & 3 & $\begin{array}{l}0 \\
4\end{array}$ & $\begin{array}{l}\mathbf{0} \\
5\end{array}$ & 6 & 7 & 8 & 9 & 0 & $\begin{array}{l}1 \\
1\end{array}$ & $\begin{array}{l}1 \\
2\end{array}$ & $\begin{array}{l}\text { Tot } \\
\text { al }\end{array}$ \\
\hline IB & & & & 4 & 7 & $\begin{array}{l}2 \\
7 \\
\end{array}$ & & $\begin{array}{l}2 \\
3 \\
\end{array}$ & $\begin{array}{l}5 \\
5 \\
\end{array}$ & $\begin{array}{l}5 \\
6 \\
\end{array}$ & 7 & $\begin{array}{l}7 \\
1 \\
\end{array}$ & $\begin{array}{l}4 \\
7 \\
\end{array}$ & $\begin{array}{l}8 \\
4 \\
\end{array}$ & $\begin{array}{l}5 \\
5 \\
\end{array}$ & 489 \\
\hline $\begin{array}{l}\text { ALI } \\
\text { S }\end{array}$ & & & & & & & & & & & & & & & $\begin{array}{l}4 \\
5\end{array}$ & 45 \\
\hline
\end{tabular}




\begin{tabular}{|c|c|c|c|c|c|c|c|c|c|c|c|c|c|c|c|c|}
\hline $\begin{array}{l}\text { DJLI } \\
\mathrm{S}\end{array}$ & & & & & & & & & & & & & & & $\begin{array}{l}1 \\
7 \\
8\end{array}$ & 178 \\
\hline TIM & & & & & & & & $\begin{array}{l}1 \\
0\end{array}$ & $\begin{array}{l}2 \\
3\end{array}$ & $\begin{array}{l}2 \\
8\end{array}$ & $\begin{array}{l}2 \\
7\end{array}$ & $\begin{array}{l}4 \\
3\end{array}$ & $\begin{array}{l}4 \\
4\end{array}$ & $\begin{array}{l}8 \\
2\end{array}$ & $\begin{array}{l}3 \\
4\end{array}$ & 291 \\
\hline SJIM & $\begin{array}{l}5 \\
0\end{array}$ & $\begin{array}{l}7 \\
9\end{array}$ & $\begin{array}{l}5 \\
2\end{array}$ & $\begin{array}{l}9 \\
7\end{array}$ & 9 & 7 & 6 & $\begin{array}{l}9 \\
9\end{array}$ & $\begin{array}{l}1 \\
0 \\
1\end{array}$ & $\begin{array}{l}0 \\
9\end{array}$ & $\begin{array}{l}4 \\
0\end{array}$ & $\begin{array}{l}7 \\
3\end{array}$ & $\begin{array}{l}1 \\
5 \\
3\end{array}$ & $\begin{array}{l}1 \\
4 \\
5\end{array}$ & $\begin{array}{l}1 \\
5 \\
4\end{array}$ & $\begin{array}{l}148 \\
6\end{array}$ \\
\hline $\begin{array}{l}\text { PJLI } \\
\mathrm{S}\end{array}$ & & & & & & & & & & & & & & & $\begin{array}{l}5 \\
3\end{array}$ & 53 \\
\hline $\begin{array}{l}\text { LJLI } \\
\text { S } \\
\end{array}$ & & & 2 & 3 & 5 & 5 & $\begin{array}{l}3 \\
0 \\
\end{array}$ & $\begin{array}{l}3 \\
0 \\
\end{array}$ & 1 & & $\begin{array}{l}1 \\
3 \\
\end{array}$ & & $\begin{array}{l}1 \\
0\end{array}$ & 7 & & 106 \\
\hline $\begin{array}{l}\text { RJLI } \\
\mathrm{S}\end{array}$ & & & & & & & & & & 2 & 3 & & 5 & & & 10 \\
\hline $\begin{array}{l}\text { CUJ } \\
\text { LIS } \\
\end{array}$ & & & & 1 & $\begin{array}{l}1 \\
0 \\
\end{array}$ & 9 & 5 & 5 & 4 & $\begin{array}{l}1 \\
0\end{array}$ & $\begin{array}{l}1 \\
1 \\
\end{array}$ & $\begin{array}{l}1 \\
6 \\
\end{array}$ & 4 & 1 & 8 & 84 \\
\hline $\begin{array}{l}\text { NAL } \\
\text { IS }\end{array}$ & & & & & & & & & & & & & 4 & & & 4 \\
\hline JLIS & & & & & & & & & & & & & $\begin{array}{l}2 \\
2 \\
\end{array}$ & & & 22 \\
\hline $\begin{array}{l}\text { ILA } \\
\text { B } \\
\end{array}$ & & & $\begin{array}{l}2 \\
2 \\
\end{array}$ & $\begin{array}{l}4 \\
4 \\
\end{array}$ & $\begin{array}{l}1 \\
4 \\
\end{array}$ & & & & & 5 & & 6 & $\begin{array}{l}1 \\
0\end{array}$ & $\begin{array}{l}2 \\
5 \\
\end{array}$ & $\begin{array}{l}3 \\
0 \\
\end{array}$ & 156 \\
\hline & $\begin{array}{l}5 \\
0\end{array}$ & $\begin{array}{l}7 \\
9\end{array}$ & $\begin{array}{l}7 \\
6\end{array}$ & $\begin{array}{l}1 \\
4 \\
9\end{array}$ & $\begin{array}{l}1 \\
2 \\
7\end{array}$ & $\begin{array}{l}1 \\
1 \\
5\end{array}$ & $\begin{array}{l}1 \\
0 \\
4\end{array}$ & $\begin{array}{l}1 \\
6 \\
7\end{array}$ & $\begin{array}{l}1 \\
8 \\
4\end{array}$ & $\begin{array}{l}2 \\
1 \\
0\end{array}$ & $\begin{array}{l}2 \\
5 \\
4\end{array}$ & $\begin{array}{l}2 \\
0 \\
9\end{array}$ & $\begin{array}{l}2 \\
9 \\
9\end{array}$ & $\begin{array}{l}3 \\
4 \\
4\end{array}$ & $\begin{array}{l}5 \\
5 \\
7\end{array}$ & $\begin{array}{l}292 \\
4\end{array}$ \\
\hline
\end{tabular}

Table6: Year wise growth of Uncontrolled term in all journals

For consulting table 6, we can see from the above table that the Uncontrolled term/ Keywords Phrases used in various Journals released during a span of fifteen years starting from the year 1998 to 2012.The used of Uncontrolled terms in the starting years 1998 and 1999 was nil, which gradually increase from the year 2000 and reached its maximum level in the year 2012 which was around 2924 numbers.

\subsection{Considering Folksonomy:}

\begin{tabular}{|lcll|}
\hline Information communication & & & \\
Technology & 36 & UGC-INFONATE & 9 \\
& & Information seeking & \\
Authorship Pattern & 20 & Behavior & 8 \\
Scientometric & 19 & Job Satisfaction & 8 \\
Bibliometric Studies & 16 & Metadata & 8 \\
& & Analytico Synthetic & \\
Citation Analysis & 16 & Classification & 7 \\
Librarian & 16 & Author Productivity & 7 \\
Library Service & 12 & Internet Use & 7 \\
World Wide Web & 11 & Case Study & 6 \\
Information Literacy & 11 & Informatics & 6 \\
DSpace & 10 & Reading Habit & 6 \\
Publication productivity & 10 & Virtual Library & 5 \\
Publication productivity & 10 & Webometrics & 5 \\
User Studies & 10 & Information Technology & 5 \\
LIS Professional & 10 & Electronic Books & 5 \\
Institutional Repository & 10 & Electronic Learning & 5 \\
\hline
\end{tabular}


In view of the usage keywords used in the last fifteen years. We have found the usage of uncontrolled keywords have come in to consideration accounts. We have found that thirty terms are used 315 times. We can confuse that if a keywords is being used for more than ten tomes, then we can term them as "folksonomy ".but the gradation of commonly used keywords is not bound to more than 10 times. In recent future, these can be considered as "Folksonomy". "Information Communication Technology" and "Scientrometrics"," Author ship Pattern" Keywords are used 36 and 20 times. The keywords used less then 5 to 10 times can be used as folksonomy of their usage are found to be rapidly increase.

There is no guideline or rules standard to identify a term as folksonomic term. We have no idea, after how many occurrences or after how many years a term becomes a folksonomic term. The general conceptions of a folksonomical term are that which generates automatically and accepted or used by the common people. For our consideration we have found four terms are used more than ten times. But is also not included any standard vocabulary tools. So we have considered these terms are folksonomic terms. Among of them "Information communication Technology" terms is used thirty six times. Rest of twenty eight terms are used in more than five times, so in future, we considered that these terms may be folksonomical terms.

Folksonomy is the uncontrolled usage terms/phrases. Folksonomies are thus created by the people for the people on the basis of the premise that people can create a categorization that will better reflect the people's conceptual model. Keeping in mind this concept, we may consider those terms given in example above the proposed model of technical folksonomy. eg.-

\section{Bibliographic Control}

$\begin{array}{ll}\text { UC } & \text { Bibliographic record control } \\ \text { BC } & \text { Library and Information Science } \\ \text { NC } & \text { Metadata } \\ & \text { Database } \\ \text { RC } & \text { Authority Control } \\ \text { R } & \text { Use for Library Science }\end{array}$

\subsection{Conclusion:-}

Finally the study clearly shows that trend of usage of folksonomy are increasing day by day in LIS domain. This tiny research study is based on broad concept of folksonomy. We did not find any model folksonomic vocabulary system. Thus the hypothesis we set become positive.

With the invention of internet, the style representation and publication nascent micro thought have been changed remarkable in various subjects. Library and Information Science is no exception. Last few year years it has been found that to represent the thought content the authors of Library and Information Science are using more and more phrases, natural languages than the standard control vocabulary and thus developed a new style and terms popularly known as folksonomy to represent the thought content of subjects. So we should accept and 
welcome Folksonomical tagging system for creating metadata system and to create a proposed model which may include any standard tools. And information retrieval process for multi- indexing and also adding future social OPAC (SOPAC) system for library and information centre.

\section{Reference:-}

1. Abel $\mathrm{F}$, Leveraging search and content exploration by exploiting context in folksonomy systems,New Review of Hypermedia and multimedia,16 (2) (2010)5-9.

2. An M G, Video summarisation based on collaborative temporal tags, Online Information Review. 23(2) (2011) 303-325.

3. Bateman, SCollaborative tagging : Folksonomy ,metadata, visualization, ELearning, Thesis. University of Saskatchewan .

4. Brathen, J. (2009). An analysis of image folksonomy generation.

5. Chan, K. Y. (2009). Linking folksonomy to Library of Congress subject headings:an exploratory study. Journal of Documentation .

6. Francisco Echarte, J. J. (2007). Ontology of Folksonomy: A New Modeling Method.

7. Ikki Ohmukai, M. H. (2004). A Proposal of Community-based Folksonomy with RDF Metadata.

8. Karch, M. (2006) Folksonomy based tag recommendation.Journal of library Metadata.

9. Knerr, T. (2005). Tagging Ontology - Towards a Common Ontology for Folksonomies.

10. Martin Szomszor, H. A. (2008). Semantic Modelling of User Interests Based on Cross-Folksonomy Analysis. SIWS .

11. Mas, M. D. (2010). Intelligent interface architectures for folksonomy driven structure network.

12. Mathes, A. (2004). Folksonomies - Cooperative Classification andCommunication Through Shared Metadata. . Computer Mediated Communication .

13. Noruzi, A. (2006). Folksonomies: (Un)Controlled Vocabulary? Knowledge Organization, 119-133p.

14. Russell, T. (2005). Contextual Authority Tagging:Cognitive Authority through Folksonomy. SLIS .

15. Vig, J. (2010). Intelligent Tagging Interfaces: Beyond Folksonomy. TIST .

16. $\mathrm{Wu}, \mathrm{Z}$. (2002). Tagging:Marrying folksonomy and ontology. Beijing Broadcasting Institute . 